\title{
"Cognitive modeling of factors of influence on the processes of formation and reproduction of fixed assets of agricultural enterprises"
}

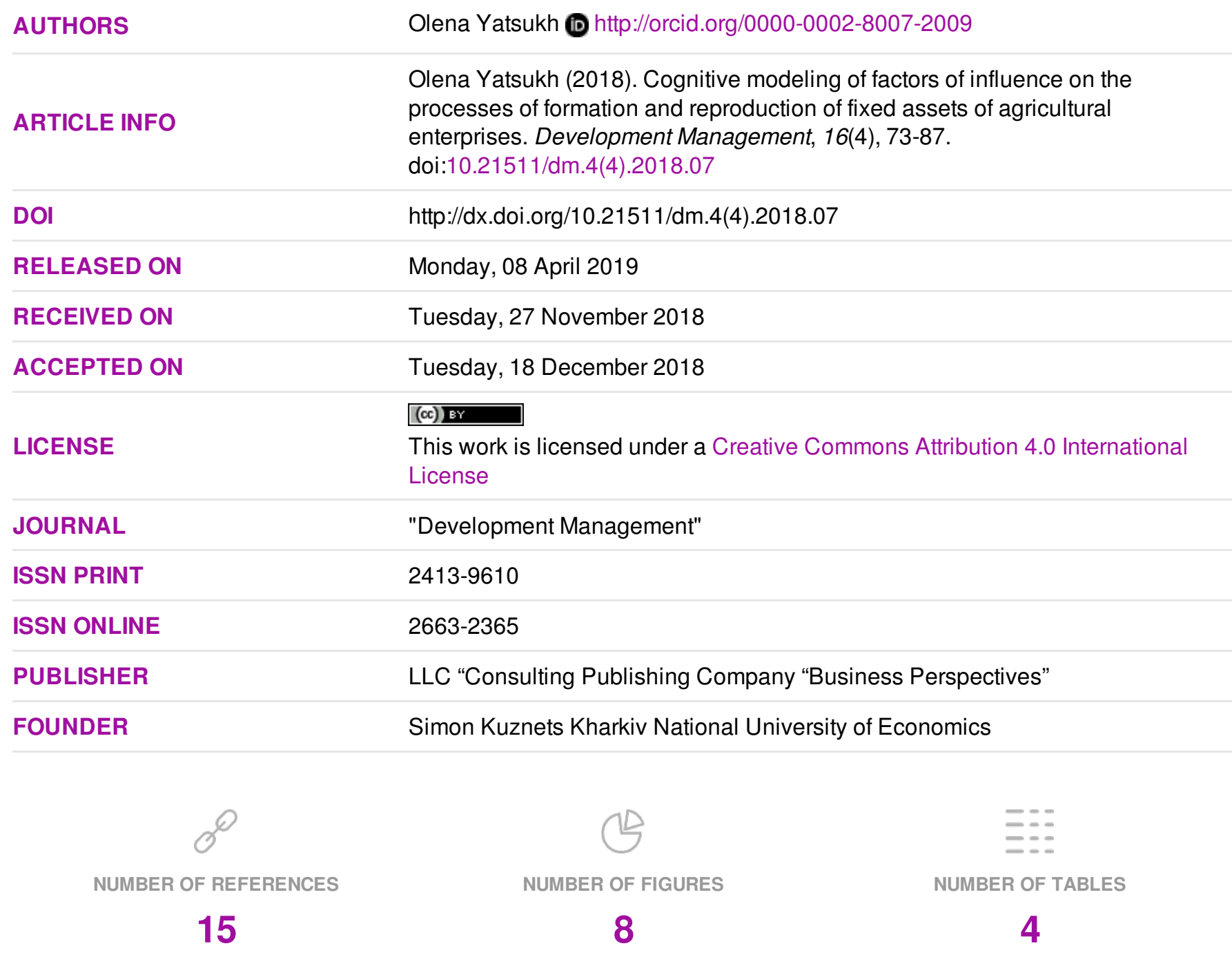

(C) The author(s) 2023. This publication is an open access article. 


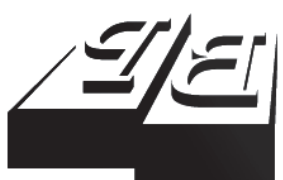

BUSINESS PERSPECTIVES

Publisher:

LLC "CPC "Business Perspectives" Hryhorii Skovoroda lane, 10, Sumy, 40022, Ukraine www.businessperspectives.org

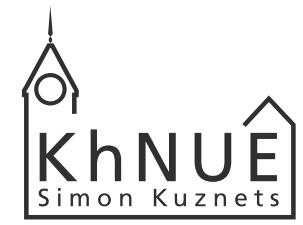

\section{S. KUZNETS KHNUE}

Founder:

Simon Kuznets Kharkiv National University of Economics, Nauky avenue, 9-A, Kharkiv, 61166,

Ukraine

http://www.hneu.edu.ua/

Received on: 27th of

November, 2018

Accepted on: 18th of

December, 2018

\section{๑) Olena Yatsukh, 2018}

Olena Yatsukh, Ph.D, Assistant Professor, Head of Department of Finance, Banking and Insurance, Tavria State Agrotechnological University, Ukraine.

\section{(c) (1)}

This is an Open Access article, distributed under the terms of the Creative Commons Attribution 4.0 International license, which permits unrestricted re-use, distribution, and reproduction in any medium, provided the original work is properly cited.

\title{
COGNITIVE MODELING OF FACTORS OF INFLUENCE ON THE PROCESSES OF FORMATION AND REPRODUCTION OF FIXED ASSETS OF AGRICULTURAL ENTERPRISES
}

\begin{abstract}
The features of financial support for reproduction of fixed assets of agrarian enterprises are considered in the article. These include quantitative and qualitative differences in the basic assets of agrarian enterprises, seasonal production, long payback period of capital investments, the reproduction in agricultural enterprises of a significant part of fixed assets in kind, unsustainable financial condition of enterprises and lack of collateral for obtaining long-term loans, undervalued value of fixed assets, no accrual of depreciation on land. For the agricultural enterprises of Ukraine, a cognitive model of the situation «Fixed Assets» was developed, which allows us to investigate factors that determine the possibilities of expanding their reproduction in the light of unstable conditions of functioning. On the basis of cognitive modeling, studies of a possible scenario for the transformation of this system in accordance with the purpose of management have been carried out and modeling the dynamics of the levers of directing the management influences depending on the chosen behavior. It is established that the most significant factors influencing changes in the system of fixed assets are: net profit received by enterprises of the agrarian sector of Ukraine, state support of agricultural producers, foreign investments in agriculture and financing of fixed assets on the basis of leasing. Based on a correlation-regression analysis based on the estimation of stable cause-and-effect relationships, establishing quantitative relations between random variables of the investigated process, conditional forecasts of changes in the size of fixed assets of agricultural enterprises are constructed.
\end{abstract}

\section{Keywords}

JEL Classification

О.О. Яцух (Україна)

\section{КОГНІТИВНЕ МОДЕЛЮВАННЯ ФАКТОРІВ ВПЛИВУ НА ПРОЦЕСИ ФОРМУВАННЯ І ВІДТВОРЕННЯ ОСНОВНИХ ЗАСОБІВ СІЛЬСЬКОГОСПОДАРСЬКИХ ПІДПРИЕМСТВ}

\begin{abstract}
Анотація
У статті розглянуті особливості фінансового забезпечення відтворення основних засобів підприємств аграрної галузі. До них віднесені кількісні і якісні відмінності основних засобів аграрних підприємств, сезонність виробництва, тривалий термін окупності капітальних інвестицій, здійснення відтворення в сільськогосподарських підприємствах значної частини основних засобів у натуральній формі, нестійкий фінансовий стан підприємств і брак застави для отримання довгострокових кредитів, заниження вартості основних засобів, відсутність нарахування амортизації на землю. Для сільськогосподарських підприємств України побудована когнітивна модель системи «Основні засоби», яка дає змогу дослідити фактори, що
\end{abstract}


визначають можливості розширення їх відтворення з урахуванням нестабільних умов функціонування. На базі когнітивного моделювання проведені дослідження можливого сценарію трансформації цієї системи відповідно до мети управління та здійснено моделювання динаміки важелів спрямування керівних впливів в залежності від обраної поведінки. Встановлено, що найбільш значимими факторами, які впливають на зміни в системі «основні засоби» є: чистий прибуток, що отримують підприємства аграрної галузі України, державна підтримка сільськогосподарських товаровиробників, іноземні інвестиції у сільське господарство та фінансування основних засобів на основі лізингу. На основі кореляційно-регресійного аналізу, що заснований на оцінці стійких причинно-наслідкових зв'язків, що встановлюють кількісні співвідношення між випадковими величинами досліджуваного процесу, в роботі побудовані умовні прогнози зміни розміру основних засобів сільськогосподарських підприємств.

\section{Ключові слова}

когнітивне моделювання, основні засоби, фінансові ресурси, сільськогосподарські підприємства, обсяг виробництва продукції, оподаткування, державна підтримка, лізинг,

Класифікація JEL банківське кредитування G17, Q14

\section{ВСТУП}

Результативність діяльності будь-якого підприємства зумовлена як наявністю, так і якістю основних засобів, що забезпечують процес її здійснення. Особливо актуальним це питання є для сільськогосподарських підприємств, оскільки останнє десятиліття коефіцієнт зносу основних засобів коливається у межах 36-42\%. Останнє, відповідно, зумовлює необхідність пошуку фінансових ресурсів задля їх оновлення. Низький рівень відтворювальних процесів у підприємствах аграрного сектору пов'язаний з порушенням базових основ здійснення амортизаційної, цінової та інвестиційної політики. Відзначимо, що не дивлячись на прибуткову роботу галузі, власних коштів для своєчасного оновлення основних засобів у сільськогосподарських товаровиробників не вистачає, що обумовлено рядом причин, серед яких на перший план висувається специфіка аграрного виробництва, тобто неспівпадіння періоду вкладення коштів і отримання виручки від реалізації продукції, та значний вплив на ці процеси інфляції, навіть у короткостроковому періоді. Важливим фактором при цьому є відсутність паритету цін на продукцію аграрного виробництва і продукцію галузей промисловості. Досить складним на сьогодні $\epsilon$ залучення зовнішніх фінансових ресурсів шляхом банківського кредитування. Це пов'язано як із нестійким фінансовим станом багатьох сільськогосподарських підприємств i, як наслідком, низьким рівнем кредитоспроможності, так і зависокими відсотковими ставками. 3 іншого боку, останні роки розширилися можливості залучення ресурсів за допомогою лізингових операцій.

Щодо інвестицій, то їх вкладення обмежується лише найбільш прибутковими напрямами сільськогосподарського виробництва, внаслідок чого виникає певний дисбаланс: галузі які потребують докорінної модернізації на основі довгострокового вкладення капіталу залишаються без додаткових ресурсів, тоді як продовжується фінансування тих напрямів, які дозволяють інвесторам швидко отримувати прибуток.

В той же час звужуються обсяги державної підтримку, що мала 6 регулювати процеси оновлення основних засобів аграрної галузі. Такі суперечливі умови функціонування сільськогосподарських підприємств потребують використання сучасних методик, які дозволяють виокремити стратегічні напрями їх подальшого розвитку в цілому, і оновлення основних засобів зокрема. Однією з таких методик $\epsilon$ когнітивне моделювання, яке має знизити рівень невизначеності розвитку подій шляхом використання експертний оцінок, сценарного прогнозування розвитку проблемної ситуації та адекватного формування цільових орієнтирів.

\section{1. ЛІТЕРАТУРНИЙ ОГЛЯА}

НаприкінціминулогостоліттятакііноземнівченіякАкселрод,Коско,Еденвизначилиосновніметодологічні підходи когнітивного моделювання та аналізу при прийняті стратегічних управлінських рішень при умові невизначеності поведінки основних векторів розвитку системи в подальшому просторовому вимірі. Вперше методику когнітивного моделювання динамічних систем було запропоновано американським 
вченим Акселродом (1976) [1]. Еден обгрунтував в своїх наукових працях у 1988 році [3] використання когнітивної карти, як основного інструменту когнітивного моделювання, яка представлена як різновид математичної моделі для узагальнення та формалізації проблеми функціонування складної системи в умовах невизначеності у вигляді множини складових, що відображають їі взаємопов’язані змінні системні фактори і дають можливість виявлення причинно-наслідкових відношень (відношень впливу) між ними. Особливу практичну цінність при побудові моделі взаємозв’язків на основі когнітивного моделювання мають нечіткі когнітивні карти Коско (1986), де змінні, що характеризують якісний стан факторів та зв’язки між ними приймають нечіткі значення [6]. Отже, у когнітивній карті представлені напрямки взаємодії ключового об’єкта і об’єктів зовнішнього середовища, встановлюються між ними якісні (причинно-наслідкові) зв’язки в ході їх зміни та умов функціонування всієї системи. Основні елементи когнітивної карти - фактори і причинно-наслідкові зв’язки між ними. Для того, щоб зрозуміти і проаналізувати поведінку складної системи, будують структурну схему причинно-наслідкових зв’язків елементів системи (факторів ситуації).Формально когнітивна карта має вигляд орієнтованого графа, вершинами якого $є$ фактори, а ребрами - зв’язок між ними. Фактори можуть впливати один на інший; такий вплив буває позитивним, коли збільшення (зменшення) одного фактору приводить до збільшення (зменшення) іншого фактору, і негативним, коли збільшення (зменшення) одного фактору приводить до зменшення (збільшення) іншого фактору. Іноді вплив може мати змінний знак залежно від можливих додаткових умов. Позитивні зв'язки між вершинами моделі позначаються суцільними дугами, а негативні - пунктирними лініями [5].

За визначенням Робертса (1978) «знаковий граф (знаковий орграф) - це граф, в якому ... вершини відповідають членам групи; з вершини $V$, в вершину проводиться дуга, якщо спостерігається чітко виражене ставлення У; до $V$, причому дуга вд $=(V,, V])$ має знак плюс (+), якщо $V$, «симпатизує» $У \wedge ~ i$ знак мінус (-) в іншому випадку» [11].

Шаховалова (2017) на основі аналізу практики відтворення основних засобів аграрних підприємств виділяє такі його особливості, які впливають на фінансове забезпечення:

- кількісні і якісні відмінності основних засобів (в аграрних підприємствах використовуються та входять до складу основних засобів, крім технічних засобів, земельні ділянки, капітальні витрати на поліпшення земель, тварини та багаторічні насадження);

- капітальні інвестиції в аграрних підприємствах мають тривалий термін окупності і супроводжуються значними ризиками, невизначеністю при очікуванні результату;

- відтворення в аграрних підприємствах значної частини основних засобів у натуральній формі (частина виробленої продукції залишається на підприємствах для власних потреб), що зменшує величину отриманого прибутку;

- сезонність виробництва (розриви в надходженні фінансових ресурсів та їх витраченні);

- різниця у виробленому продукті, його призначенні та якостях, пристосованістю до процесу обігу (в сільському господарстві має місце сезонність виробництва і безперервність споживання, що вимагає фінансових ресурсів для забезпечення зберігання продукції);

- брак застави для отримання довгострокових кредитів (більшість оброблюваних земель використовуються аграрними підприємствами на правах оренди, а також в Україні немає ринку землі та не можуть бути заставою, активна частина матеріально-технічних основних засобів має високий рівень зносу);

- заниження вартості основних засобів, що скорочує фінансові ресурси в формі амортизаційних відрахувань на відтворення основних засобів і негативно впливає на процес їх відтворювання;

- відсутність нарахування амортизації на землю [13].

Вказані особливості дозволяють стверджувати, що процес фінансування оновлення основних засобів $€$ складною слабоструктурованою системою. Зокрема, під слабоструктурованими Шемаєва (2005) розуміє системи, поведінка яких описується на якісному рівні, а зміна параметрів таких систем може привести до непередбачених змін іï структури [14]. Як наслідок маємо неможливість отримання адекватних взаємозв’язків за результатами статистичного спостереження. 
Таким чином, багатовекторність в системі фінансового забезпечення аграрної галузі породжує різноплановість політики залучення фінансових ресурсів для оновлення основних засобів, що потребує певної стратегії управління нею і розробки управлінських рішень, які 6 спиралися на використання когнітивного моделювання. Крім того, на сьогодні не було сформовано перелік факторів, що дозволили 6 пов'язати поточний стан об'єктів і сценарії реалізації рішень з майбутніми станами системи «основні засоби» для сільськогосподарських підприємств.

\section{2. МЕТА АОСЛІДЖЕННЯ}

Метою дослідження $є$ визначення основних факторів впливу на формування основних засобів сільськогосподарських підприємств у сучасних умовах господарювання та на основі використання когнітивного моделювання поведінки зазначеної системи прогнозування сценаріїв.

\section{3. МЕТОДИ ДОСЛІДЖЕННЯ}

При написанні роботи використані діалектичний метод пізнання, аналіз і синтез, методи фінансового та економіко-статистичного аналізу - при дослідженні джерел фінансового забезпечення відтворення основних засобів сільськогосподарських підприємств та формуванні комплексу факторів, що впливають на цей процес. Крім того, використовувались й інші традиційні методи досліджень: індукція, дедукція, абстракція, спостереження, порівняння, аналогія, узагальнення.

Оцінка факторів впливу на процеси формування і відтворення основних засобів сільськогосподарських підприємств здійснювалася на основі когнітивного моделювання.

Когнітивна структуризація досліджуваної системи «основні засоби» базується на узагальненні думок експертів.

При аналізі ситуацій, що спираються на моделі когнітивних карт, вирішуються два типи завдань: статичні і динамічні. Статичний аналіз - це аналіз поточної ситуації, що включає дослідження впливів одних факторів на інші, дослідження стійкості ситуації в цілому і пошук структурних змін для отримання стійких структур.

Динамічний аналіз - це генерація і аналіз можливих сценаріїв розвитку ситуації в часі. Математичним апаратом аналізу $є$ теорія знакових графів і нечітких графів.

Під впливом різних збурень значення змінних у вершинах графа можуть змінюватися; сигнал, що надійшов в одну з вершин, поширюється по ланцюжку на інші, посилюючись або затухаючи.

Імпульсне моделювання - це моделювання розповсюдження збурень на когнітивних картах, що викликається внесенням збурень-імпульсів у вершину (сукупність вершин) когнітивної карти. Об’єкт моделювання можна розглядати як сукупність взаємодіючих між собою динамічних процесів, що протікають в реальному часі.

Сценарний аналіз дозволяє судити про поведінку системи, науково передбачити шляхи ï можливого розвитку.

\section{4. РЕЗУЛЬТАТИ}

Когнітивне моделювання є одним із нових напрямів сучасної теорії підтримки і прийняття управлінських рішень у різних галузях діяльності. 
В основі стандартного когнітивного підходу знаходиться декілька припущень. По-перше, знання представляють як центральну категорію. По-друге, всі когнітивні системи являються символічними: мова - це система символів, які зібрані в моделі. По-третє, когнітивні системи працюють на основі внутрішньої та зовнішньої символізації ситуацій і подій та маніпуляцій з цими символами. По-четверте, теорія пізнання може розглядатися як програма з символьним формалізмом, яка пристосована до конкретного середовища для того, щоб спостерігати окрему поведінку [4].

Когнітивна методологія для дослідження складних систем, що розвивається в даний час, включає методи вирішення послідовності системних задач: ідентифікації об’єкта і навколишнього середовища у вигляді когнітивної моделі (застосування експертних, статистичних та інших методів); аналізу шляхів і циклів когнітивної моделі (методи теорії графів); аналізу спостережливості, керованості, стійкості, чутливості, адаптованості (методи теорії управління); декомпозиції; аналізу різних аспектів складності, аналізу зв’язності (методи теорії графів, топологічний аналіз); прийняття рішень в умовах різного роду невизначеності (методи теорії прийняття рішень), супутньої існування і вивчення складної системи [15].

Мета когнітивного моделювання полягає в генерації і перевірці гіпотез про поведінку обраної системи для дослідження на основі визначення основних факторів впливу на неї та прогнозному спостереженні можливих сценаріїв її розвитку.

Методика когнітивного аналізу складних ситуацій передбачає здійснення ряду дій аналітичного характеру, а також розрахунково-обчислювальних операцій відповідно до заданого алгоритму і містить такі етапи:

1. формулювання завдання і цілі дослідження;

2. системне концептуальне дослідження ситуації;

3. структурування знання щодо предметної області;

4. побудова когнітивної моделі досліджуваної ситуації;

5. структурний аналіз когнітивної моделі;

6. моделювання, засноване на когнітивному підході;

7. предметна інтерпретація результатів моделювання [12].

У процесі управління будь якою економічною системою, яка функціонує в сучасних умовах багатофункціонального впливу їі складових на кінцевий результат, виникає цілий ряд питань щодо пріоритетних напрямків розвитку такої системи, визначення впливу їі основних складових та принципових векторів побудови взаємозв'язків між ними. Найчастіше всього є усвідомлення, що система працює незадовільно, проте не має чітко с прогнозованих, математично прорахованих наслідків, сценаріїв їі функціонального розвитку при прийняті тих чи інших управлінських рішень.

Когнітивні моделі будуються експертом (групою експертів) у заданій предметній сфері на підставі теоретичної, статистичної та експертної інформації про об'єкт дослідження [8]. Адекватність моделі визначається повнотою комплексу вихідних знань; модель може уточнитися в процесі дослідження та застосування, будучи сама по собі джерелом структурованих знань. Таким чином, когнітивна модель - це узагальнена структура знань, графічне формалізоване представлення зв’язків між концептами (поняттями, факторами, показниками) регіонального розвитку [8]. При цьому мета управління полягає у забезпеченні бажаних змін цільових факторів при виробленні рішень з управління процесами в ситуації [12].

При дослідженні системи були виокремлені основні фактори, що впливають на процес фінансування оновлення основних засобів сільськогосподарських підприємств: обсяги виробництва сільськогосподарської продукції, розмір отриманого сільськогосподарського прибутку, власний капітал та наявність фінансових ресурсів в господарській діяльності, розмір зобов'язання і забезпечення підприємства. також при формуванні когнітивної моделі враховані такі складові впливу, як розмір державної підтримки, податкових зобов’язань, розмір банківського кредитування, лізингових операцій, страхування, експорту та надходжень іноземних інвестицій. 
Фактори можуть впливати один на одного, причому такий вплив, може бути позитивним, коли збільшення (зменшення) одного фактору приводить до збільшення (зменшення) іншого чинника, і негативним, коли збільшення (зменшення) одного фактору приводить до зменшення (збільшення ) іншого чинника. Причому, вплив може мати і змінний знак в залежності від можливих додаткових умов, істотні і ключові пункти [7].

При визначенні факторів, що впливають на систему «основні засоби» і оцінки причинно-наслідкових зв’язків між ними використовували в роботі опитування групи експертів.

На підставі карти напрямків взаємозв'язків системи основний капітал складена когнітивна карта, де при позитивному зв'язку збільшення значення фактору-причини призводить до збільшення значення фактору-наслідку, а при негативному зв'язку збільшення значення фактору-причини призводить до зменшення значення фактору-слідства [7].

Когнітивна карта і сценарний підхід при аналізі системи «основні засоби» дає можливість визначити вплив зовнішнього і внутрішнього середовища на ефективність формування і використання ресурсів для розширення фінансування основних засобів, дозволяє виявити, які параметри потребують прискореного розвитку і вимагають зміни.

Когнітивна модель системи «основні засоби» надана у вигляді графа:

$\mathrm{G}=(\mathrm{V}, \mathrm{E}), \mathrm{V}=\left\{\mathrm{x}_{1}, \mathrm{x}_{2}, \mathrm{x}_{3}, \mathrm{x}_{4}, \mathrm{x}_{5}, \mathrm{x}_{6}, \mathrm{x}_{7}, \mathrm{x}_{8}, \mathrm{x}_{9}, \mathrm{x}_{10}, \mathrm{x}_{11}, \mathrm{x}_{12}\right\}$,

де $V$ - безліч вершин графа, відповідних зовнішніх і внутрішніх чинників системи основний капітал, $E$ безліч дуг, що відображають факт безпосереднього впливу параметрів один на одного.

Матриці взаємозв’язків параметрів, представлені матрицею суміжності $R_{j}$ системи основний капітал:

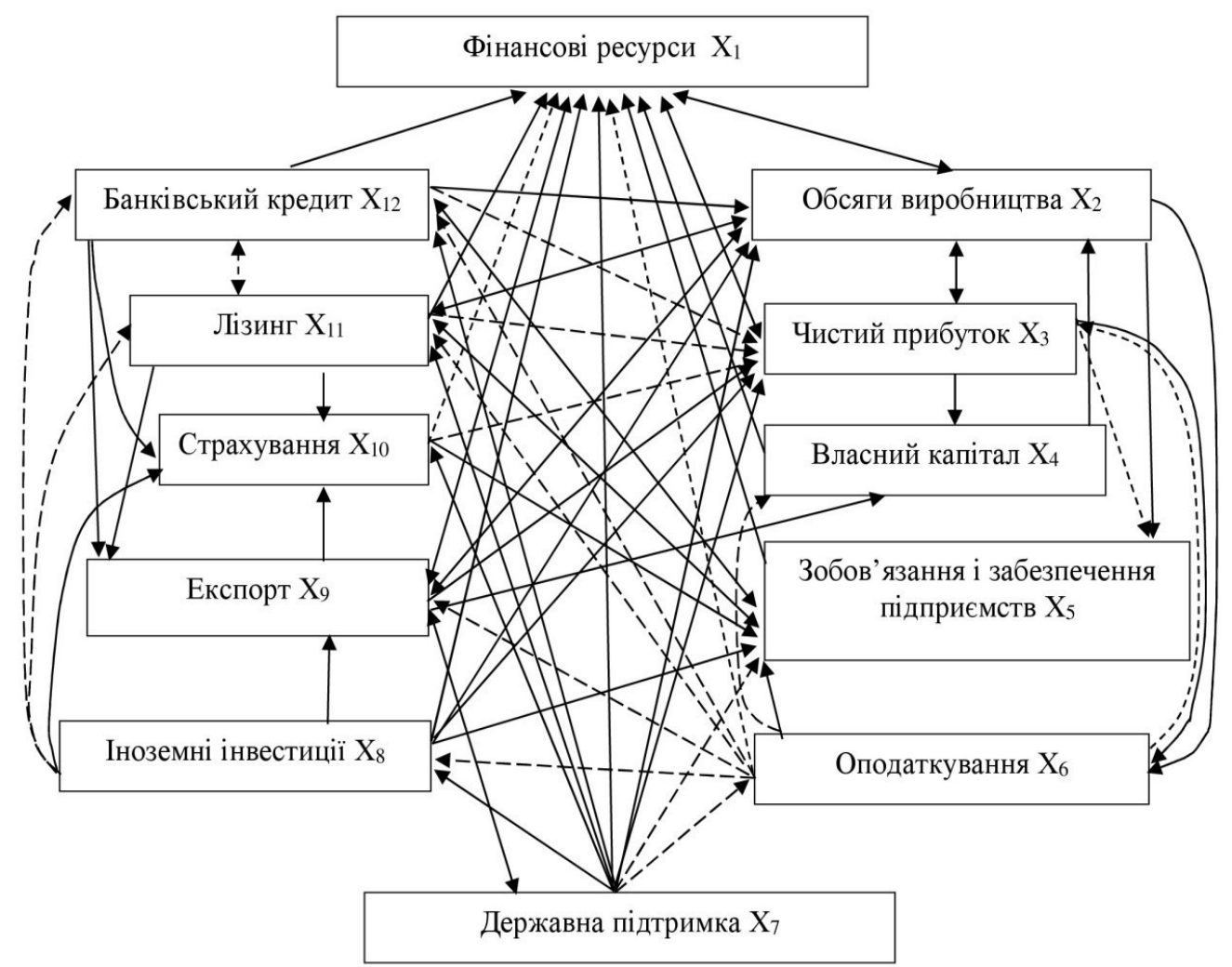

Рисунок 1. Когнітивна карта напрямків взаємозв’язків системи «основні засоби» 


$$
\mathrm{R}_{\mathrm{j}}:=\left(\begin{array}{cccccccccccc}
0 & 1 & 1 & 0 & 0 & -1 & 0 & 0 & 1 & 0 & 0 & 0 \\
1 & 0 & 1 & 0 & 1 & 1 & 0 & 0 & 1 & 0 & 1 & 0 \\
1 & 1 & 0 & 1 & 1 & 1 & 0 & 0 & 1 & 0 & -1 & 0 \\
1 & 1 & 0 & 0 & 0 & 0 & 0 & 0 & 1 & 0 & 0 & 0 \\
1 & 0 & 0 & 0 & 0 & 0 & 0 & 0 & 0 & 0 & 1 & 1 \\
-1 & 0 & 0 & -1 & 1 & 0 & 0 & -1 & -1 & 0 & -1 & -1 \\
1 & 1 & 1 & 0 & -1 & -1 & 0 & 1 & 1 & 1 & 1 & 1 \\
1 & 1 & 1 & 0 & 1 & 0 & 0 & 0 & 1 & 1 & -1 & -1 \\
1 & 1 & 1 & 1 & 0 & 0 & 1 & 0 & 0 & 1 & 0 & 0 \\
-1 & 0 & -1 & 0 & 1 & 0 & 0 & 0 & 0 & 0 & 0 & 0 \\
1 & -1 & 1 & 0 & 1 & 0 & 0 & 0 & 1 & 1 & 0 & -1 \\
1 & 1 & -1 & 0 & 1 & 0 & 0 & 0 & 1 & 1 & -1 & 0
\end{array}\right)
$$

де +1 - зростання (падіння) фактора $X i$, спричиняє зростання (падіння) $X j$; - 1 - зростання (падіння) фактору $X i$, тягне падіння (зростання) $X j ; 0$ - зв’язок між факторами Xi $i$ Xj відсутня або слабка.

Для визначення позитивного i негативного впливу факторів на систему «основні засоби» використовувалися матриці прискорення (для всіх стимулюючих) і гальмування (для всіх гальмуючих взаємодій чинників) для всіх стимулюючих та для всіх гальмуючих взаємодій [7].

Найбільш значимими факторами по взаємодії всередині системи «основні засоби» матриці прискорення та матриці гальмування $є$ : X1 - обсяги фінансових ресурсів, X2 - обсяги виробництва сільськогосподарської продукції, X3 - чистого прибутку, X7 - державної підтримки, X8 - розмір іноземних інвестицій, X9 розмір експортних операцій, X11 - розмір лізингових операцій в аграрному секторі економіки.

3 усіх факторів на підставі результатів аналізу чутливості виділені групи [7]:

8. Цільові фактори - зміна або стабілізація яких є метою управління системою «основні засоби»: X1 - фінансових ресурсів, Х2 - обсяги виробництва сільськогосподарської продукції, Х9 - обсяги експорту сільськогосподарської продукції.

9. Фактори важелі управління-керуючі фактори, потенційно впливають на систему «основні засоби»: X3 - чистий прибуток, X7 - обсяги державної підтримки, X8 - обсяги іноземних інвестицій, X11 лізингові операції.

10. Фактори індикатори - відображають і пояснюють розвиток процесу в проблемній ситуації: Х4 розмір власного капіталу, X5 - зобов'язання і забезпечення підприємств, Х6 - розмір податкових зобов’язань, Х10 - страхування сільськогосподарських підприємств, X12 - банківський кредит.

Фактори які активно впливають на систему можна представити за роллю їх впливу (Рисунок 2).

Для аналізу системи розглянуті такі етапи когнітивного моделювання: побудова когнітивної моделі та імітаційне моделювання поведінки досліджуваної системи «основні засоби» на підставі сценарного дослідження.

Сценарії дозволяють аналізувати і планувати нестандартні ситуації, дозволяють зрозуміти, за яких умов 


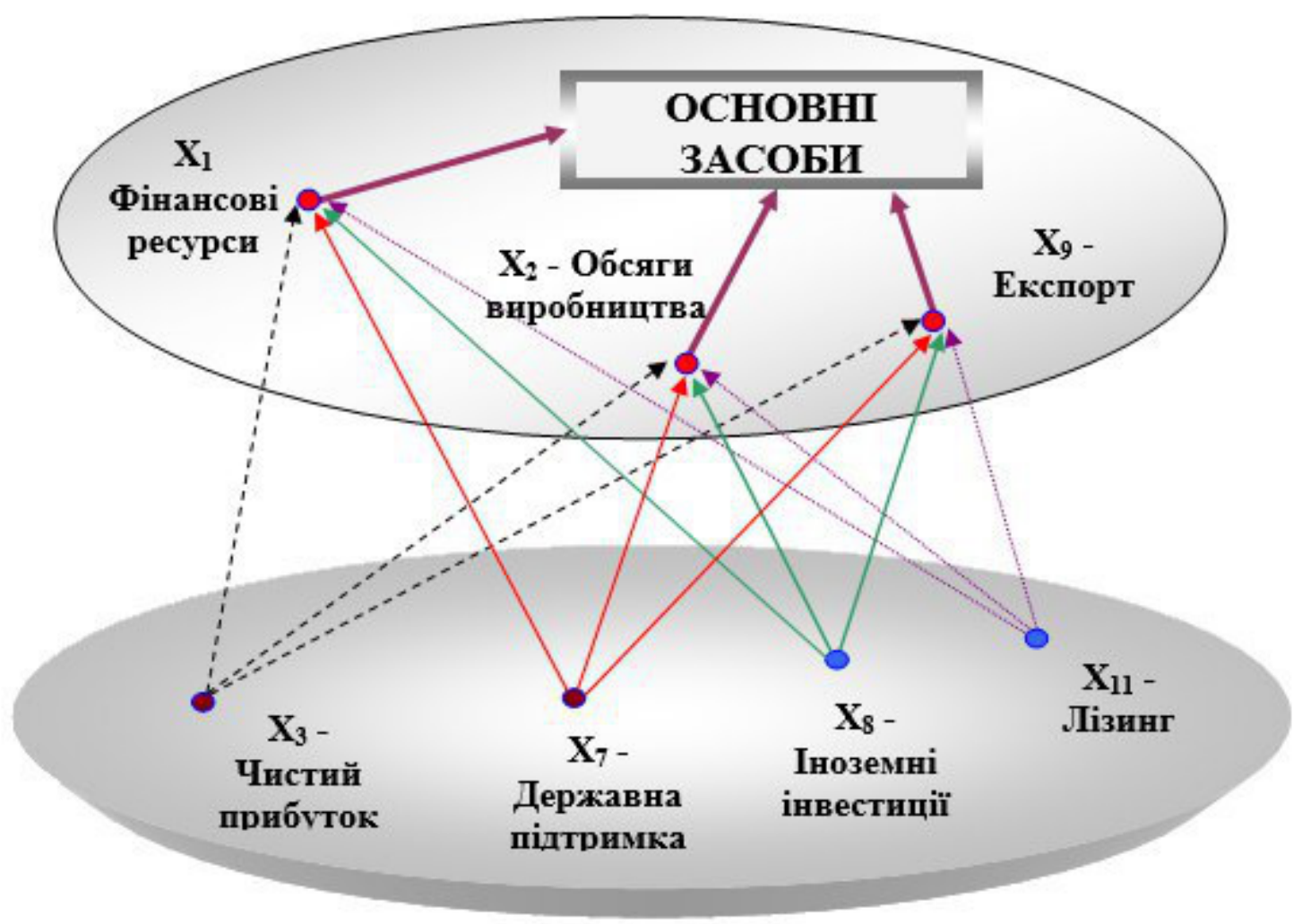

Рисунок 2. Схема впливу основних факторів системи «основні засоби»

може виникнути сприятлива або несприятлива ситуація, допомагає оцінити, як необхідно впливати на процеси, що призводять до прийнятних або неприйнятних для організації наслідків [15].

Величина імпульсу в вершині Xі в момент t описується функцією :

$\mathrm{U}_{\mathrm{i}}(\mathrm{t}+1)=\mathrm{U}_{\mathrm{i}}(\mathrm{t})+\sum_{\mathrm{j}=1}^{\mathrm{n}} \mathrm{f}\left(\mathrm{V}_{\mathrm{j}}, V_{i}\right) p_{j}(t),(1)$

де $p_{j}(t)$ в залежності від знаку дуги, що з'єднує $\mathrm{x}_{i}$ і х фактору у момент часу $t+1$ ma $t$, відповідно, $p_{j}(t)$ - зміна в вершині $\mathrm{x}_{\mathrm{j}}$ в момент часу $\mathrm{t}$ (приріст), чисельне значення вершини дорівнює 1.

$n=1 \div 12, f\left(V_{j}, V_{i}\right)$ - вага впливу фактору $x_{j \text { на }} x_{i}$.

$j \in I, I i$ - кількість факторів, що безпосередньо впливають на фактор $x_{i}$.

Отримаємо результати моделювання імпульсного процесу відповідного сценарію внесення збурень на отримані важелі.

Сценарний аналіз націлений на розширення фінансування основних засобів при завданні імпульсів в активні вершини когнітивної схеми і визначення змін значень вершин на тактах моделювання.

Під активними вершинами розуміють фактори - потенційні важелі впливу на систему: чистий прибуток - $\mathrm{X}_{3}$, державна підтримка - $\mathrm{X}_{7}$, іноземні інвестиції - $\mathrm{X}_{8}$, лізинг - $\mathrm{X}_{11}$.

При активному впливі фактору $\mathrm{X}_{3}$ - чистий прибуток (Рисунок 3), відбувається збільшення значень факторами після першого такту в кілька разів, виняток становить фактор $\mathrm{X}_{12}$ - банківський кредит та $\mathrm{X}_{10}$ - страхування і їх зростання відбувається лише після третього такту, після чого вони незначно 

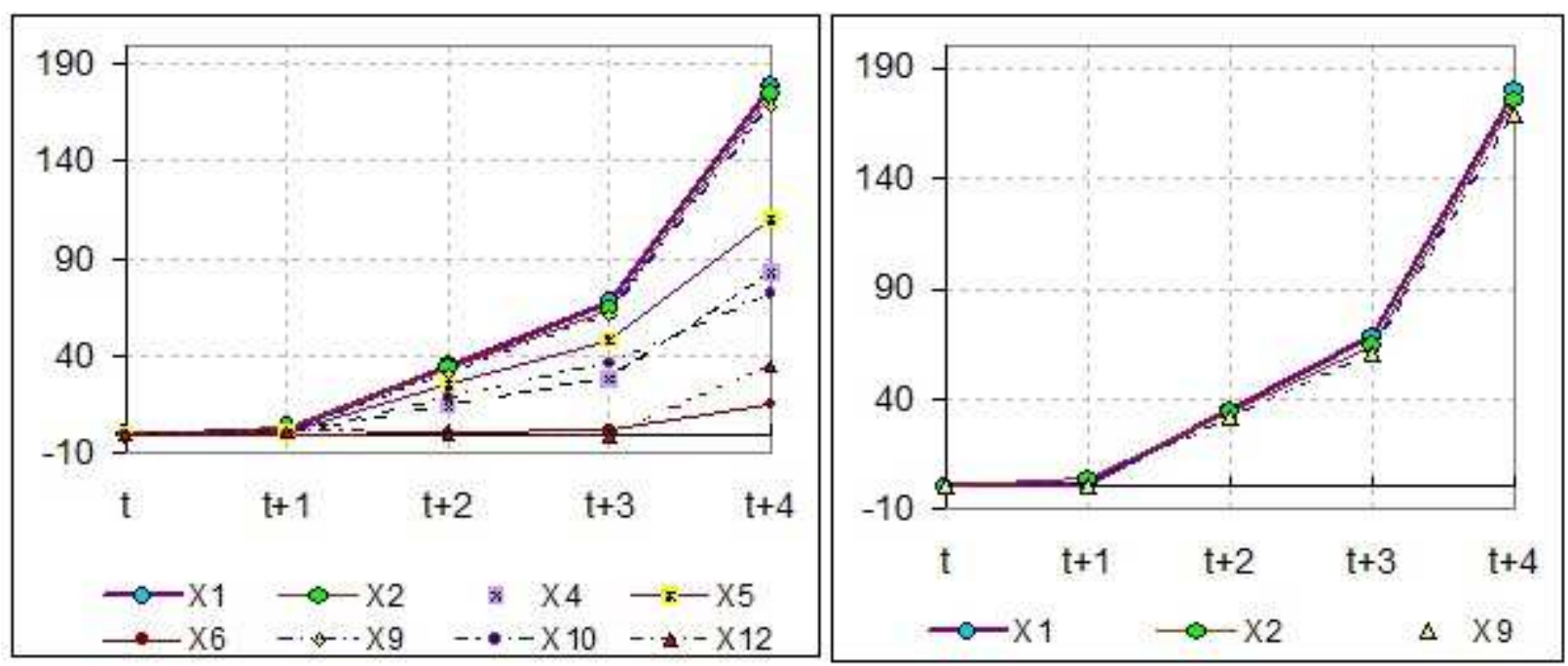

Рисунок 3. Графік внесення збурень $q=+1$ в вершину Х3 (чистий прибуток)

збільшуються.

Для цільових факторів позитивне збурення $q_{0}=+1$ в вершину $\mathrm{X}_{1}$ (чистий прибуток) фактори: фінансові ресурси $\mathrm{X}_{1}$, обсяги виробництва $\mathrm{X}_{2}$, експорт $\mathrm{X}_{9}$, збільшують свої значення після першого такту в 10 разів. Можна припустити, що вплив фактору чистий прибуток у поєднанні з іншими факторами позитивно впливає на систему «основні засоби».

При позитивному збуренні $q_{0}=+1$ в вершину $\mathrm{X}_{7}$ (державна підтримка) всі фактори збільшують свої значення після першого такту (Рисунок 4). На відміну від попереднього сценарію результати по кожному фактору вище в 2 рази. Це один з найважливіших факторів системи основний капітал.

Для цільових факторів більш наочно проглядаються зміни в системі для всіх факторів збільшуються показники після першого такту в 10 разів.

При позитивному збуренні $q_{0}=+1$ в вершину $\mathrm{X}_{8}$ (іноземні інвестиції) всі фактори збільшують свої значення після 3 такту, показники менше ніж в першому сценарії (Рисунок 5).

Для цільових факторів зміни в системі при збуренні $q_{0}=+1$ в вершину $\mathrm{X}_{8}$ (Іноземні інвестиціі) - збільшення
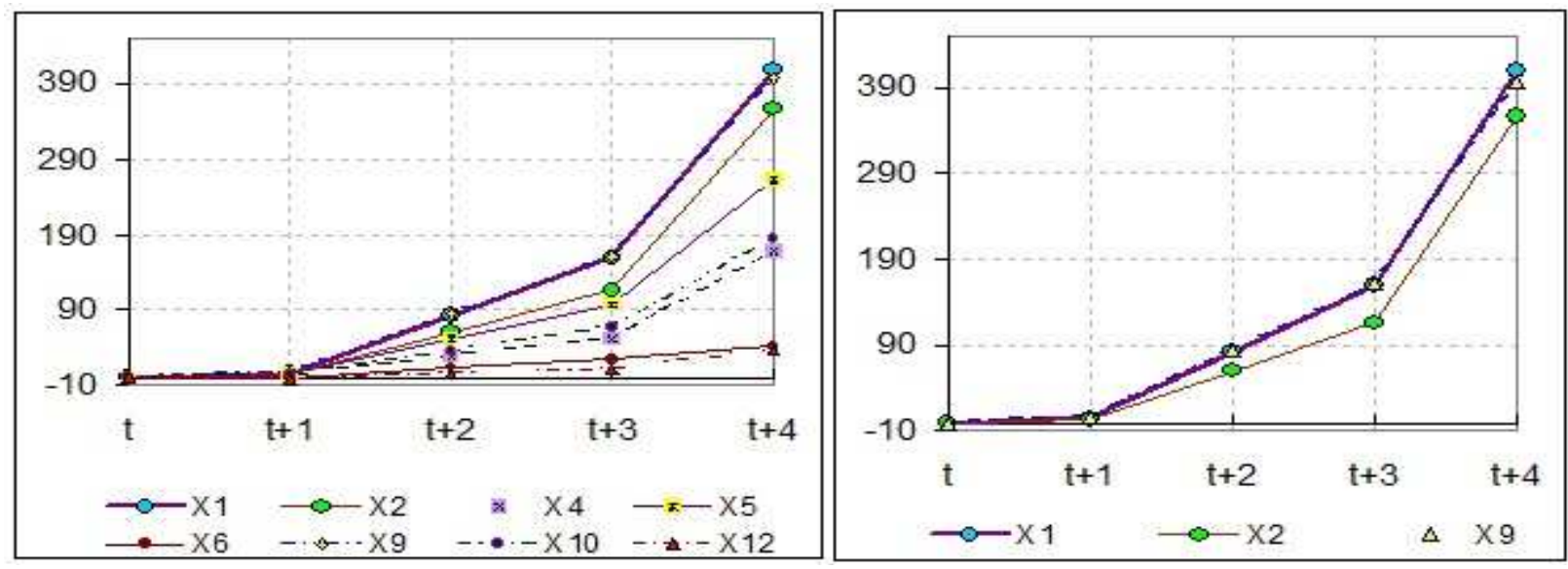

Рисунок 4. Графік внесення збурень $q=+1$ у вершини Х7 (державна підтримка) 

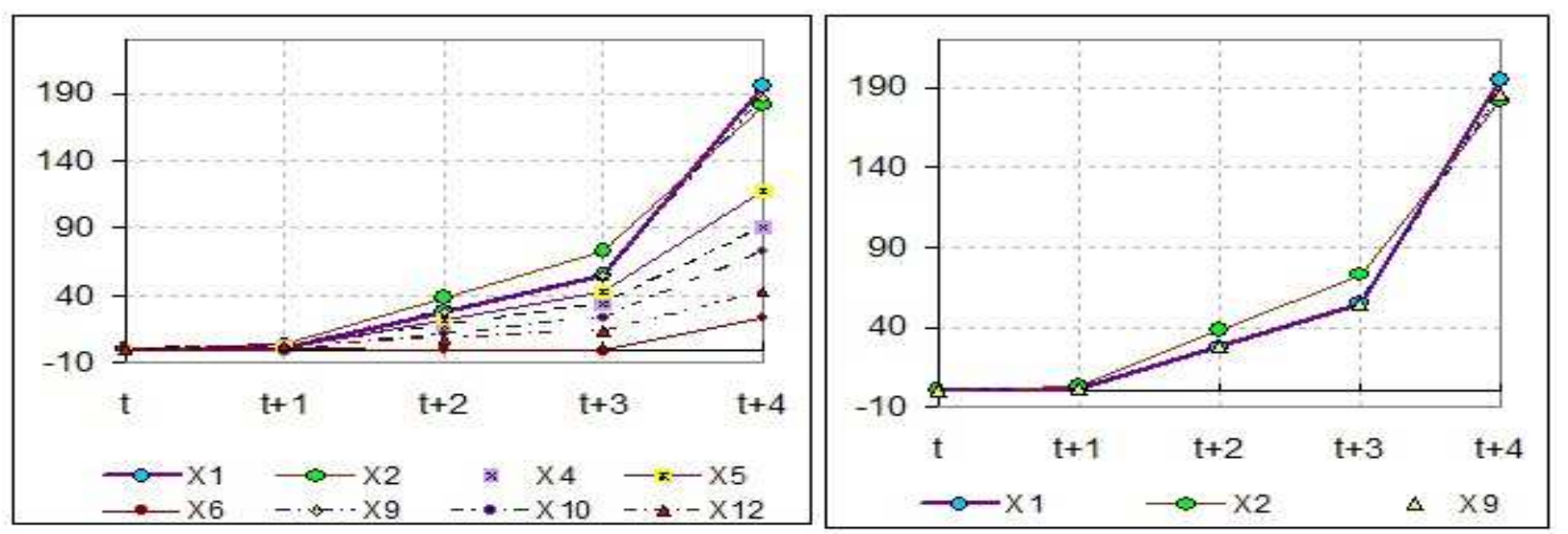

Рисунок 5. Графік внесення збурень $q=+1$ у вершини $X_{8}$ (іноземні інвестиції)
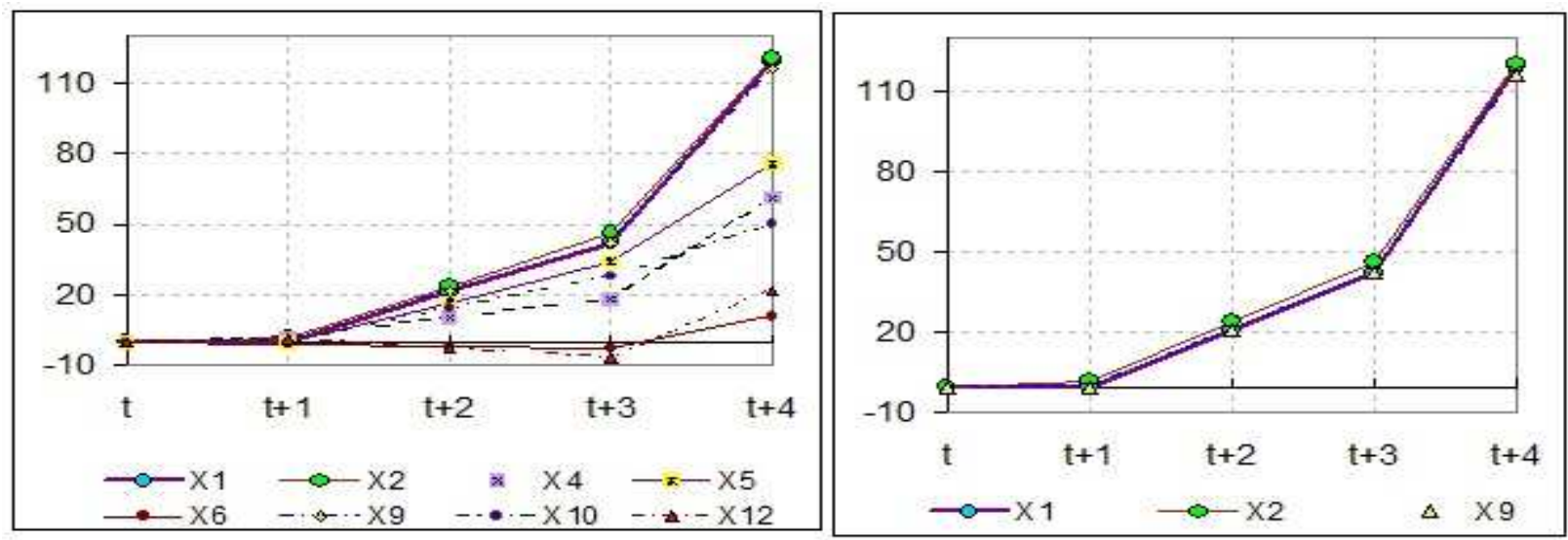

Рисунок 6. Графік внесення збурень $q=+1$ у вершину $X_{11}$ (лізингові операції)

показників після першого такту.

При позитивному збуренні $q_{0}=+1$ в вершину лізинг $\mathrm{X}_{11}$ всі фактори (Рисунок 6) значно збільшують свої значення після третього такту крім факторів банківський кредит $\mathrm{X}_{12}$ та страхування $\mathrm{X}_{10}$, які не використовуються в системі до 3 такту, після чого трохи збільшуються.

При збуренні $q_{0}=+1$ в вершину лізинг $\mathrm{X}_{11}$ всі цільові фактори збільшують свої значення при першому такті моделювання, однак ці значення в 2 рази менше, ніж в першому сценарії. Фактор чинить менший вплив на систему, ніж попередні чинники. Показники відрізняються істотно від інших сценаріїв.

Таким чином можна зробити висновок, що з розглянутих факторів найбільш активні важелі які найістотніше впливають на цільові фактори є розмір державної підтримки X7, иноземних інвестицій X8, та чистого прибутку X3.

3 метою обмеження можливих планів експерименту був розглянутий наступний план експерименту, який відображає можливі дії на чинники досліджуваної системи основний капітал.

3 розглянутих сценаріїв, відзначені наступні, у яких вплив групи факторів суттєво змінює показники по інших факторах системи «основні засоби».

Відобразимо на графіках результати сценарію, де вісь абсцис - це такти моделювання, вісь ординат - це значення факторів в умовних одиницях [15]. 
Таблиця 1. Підсумки сценарного моделювання системи «основні засоби»
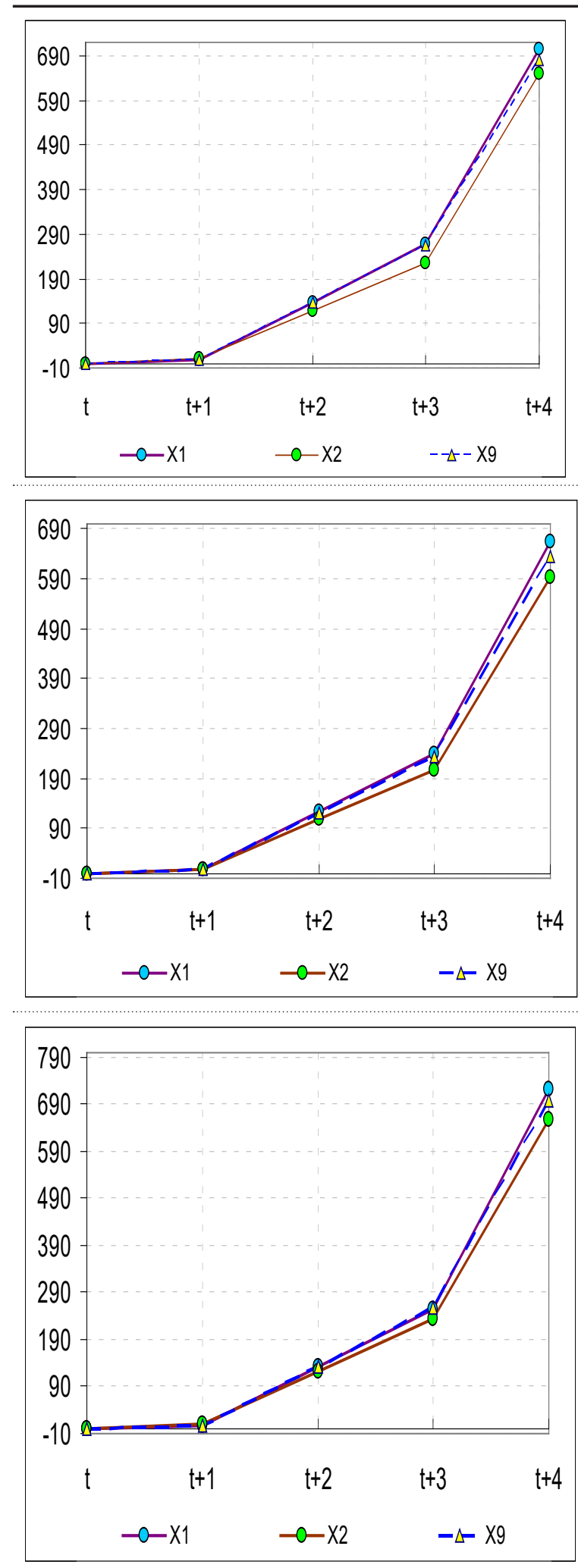

Сценарій 1.

- чистий прибуток збільшується

- д державна підтримка збільшується

- розширюються обсяги лізингових операцій

Висновок: всі показники за всіма чинниками істотно зростають в 2-3 рази після кожного такту. При комплексній дії на систему зазначених чинників спостерігається збільшення показників по кожному фрактору. Можна відзначити, що при поєднанні зазначених чинників цільові фактори системи істотно збільшать свої показники.

Сценарій 8.

- чистий прибуток збільшується

- державна підтримка збільшується

- іноземні інвестиції збільшуються

- обсяги лізингових операцій зменшуються

Висновок: Всі показники за всіма чинниками зростають з першого такту. Можна відзначити, що фрактор «іноземні інвестиції» не впливає на систему досить суттєво. Якщо проаналізувати попередній сценарій, то додався ще один показник, а графік практично не змінився. Отже, іноземні інвестиції істотно не впливають на систему

Сценарій 13

- державна підтримка збільшується

- іноземні інвестиції збільшуються

- розширюються обсяги лізингу

Висновок: Всі показники за всіма чинниками збільшуватися з 1 такту. Якщо проаналізувати попередній сценарій, то можна відзначити, що при погіршенні показників по лізингу можна компенсувати залученням іноземних інвестицій. Можна відзначити, що при поєднанні зазначених чинників цільові фрактори системи істотно збільшать свої показники.

На підставі розглянутих сценаріїв можна відзначити, що істотно на систему впливає фактор - державна підтримка, іноземні інвестиції, лізинг, чистий прибуток.

Розглянуті сценарії дозволяють зробити висновок, що основними факторами, які впливають на зміни в системі «основні засоби» $є$ : чистий прибуток $\mathrm{X}_{3}$, державна підтримка $\mathrm{X}_{7}$, іноземні інвестиції $\mathrm{X}_{8}$, лізинг $\mathrm{X}_{11}$. 
Погіршення показників одного з них призводить до негативних наслідків в системі і, навпаки, поліпшення - суттєво збільшує показники для цільових факторів системи.

Для прогнозу цільових факторів системи необхідно скласти рівняння регресії. Під час побудови кореляційно-регресійної моделі (рівняння регресії) виникає питання про тип функції, яка найкраще відображає взаємозв'язок між результативною ознакою та ознаками-факторами, тобто вибір форми зв'язку. Зв’язок між результативною ознакою «основні засоби» і цільовими факторами відображається багатофакторною моделлю (множинна кореляція).

Мета кореляційного аналізу - визначення зв’язку між випадковими змінними і оцінювання його інтенсивності та напряму. Кореляційно-регресійний аналіз застосовують для побудови умовних прогнозів, заснованих на оцінці стійких причинно-наслідкових зв'язків, спрямованих на дослідження форм зв’язку, що встановлюють кількісні співвідношення між випадковими величинами досліджуваного процесу.

Процес розрахунків із використання методу кореляційно-регресійного аналізу за даними 2008 - 2017 pр. наведено в Таблиці 2.

Таблиця 2. Показники основних мотивуючих факторів (важелів) системи «основні засоби»

\begin{tabular}{|c|c|c|c|c|c|c|c|c|}
\hline Роки & $\begin{array}{c}\text { Основні } \\
\text { засоби, } \\
\text { млн грн } \\
\text { (залишкова } \\
\text { вартість) } \\
\end{array}$ & $\begin{array}{c}\text { Фінансові } \\
\text { ресурси, } \\
\text { млн грн }\end{array}$ & \begin{tabular}{|c|} 
Обсяги \\
виробництва \\
млнгрн (y \\
цінах \\
2010 р.) \\
\end{tabular} & $\begin{array}{c}\text { Чистий } \\
\text { прибуток, } \\
\text { млн грн }\end{array}$ & $\begin{array}{c}\text { Державна } \\
\text { підтримка, } \\
\text { млн грн }\end{array}$ & $\begin{array}{c}\text { Іноземні } \\
\text { інвестиції, } \\
\text { млндоларів } \\
\text { США на } 1 \\
\text { січня }\end{array}$ & $\begin{array}{l}\text { Експорт с/г } \\
\text { продукції, } \\
\text { млндоларів } \\
\text { США }\end{array}$ & $\begin{array}{c}\text { Лізинг у } \\
\text { с/г, млнн } \\
\text { грн }\end{array}$ \\
\hline & $\mathrm{Y}$ & $\mathrm{X} 1$ & $\mathrm{X} 2$ & $\mathrm{X} 3$ & $\mathrm{X} 7$ & $\mathrm{X} 8$ & $\mathrm{X9}$ & $\mathrm{X} 11$ \\
\hline 2008 & $47,338.2$ & 130,677 & 101,451 & $5,744.3$ & $18,629.2$ & 557,3 & $10,837.6$ & 2,300 \\
\hline 2009 & $52,511.6$ & 149,536 & $96,273.6$ & $7,576.4$ & $18,758.2$ & 813,3 & $9,514.87$ & 3,200 \\
\hline 2010 & $59,424.6$ & 172,365 & 94,089 & $17,253.6$ & $21,323.9$ & 680,4 & $9,935.98$ & 4,000 \\
\hline 2011 & $71,707.7$ & 228,308 & 121,054 & 25,267 & $25,402.5$ & 730,7 & $12,804.1$ & 4,800 \\
\hline 2012 & $75,403.3$ & 276,652 & 113,082 & $26,728.4$ & $27,862.2$ & 736,3 & $17,905.6$ & 7,900 \\
\hline 2013 & 83,950 & 313,097 & 136,591 & $14,925.7$ & $26,783.5$ & 728,8 & $17,038.8$ & 9,400 \\
\hline 2014 & $87,659.2$ & 390,607 & 139,058 & $21,413.4$ & $24,985.7$ & 776,9 & 16,669 & 11,200 \\
\hline 2015 & 106,333 & 685,845 & 131,919 & 101,912 & $42,831.2$ & 617 & $14,563.1$ & 6,600 \\
\hline 2016 & 146,364 & $1,537,319$ & 145,119 & $89,816.3$ & $9,420.6$ & 502,2 & $15,281.8$ & 5,600 \\
\hline 2017 & 184,138 & 911,614 & 140,535 & $78,457.7$ & $5,294.4$ & 586,2 & $17,756.9$ & 5,500 \\
\hline
\end{tabular}

Аналіз кореляційної матриці, наведеної у Таблиці 3, свідчить, що фактори мають сильний зв’язок 3 результативною ознакою.

Таблиця 3. Кореляційна матриця факторів системи «основні засоби»

\begin{tabular}{|c|c|c|c|c|}
\hline & $\mathbf{Y}$ & $\mathrm{X} 1$ & $\mathrm{X2}$ & $\mathrm{X9}$ \\
\hline Y- основні засоби & 1 & 0.848 & 0.776 & 0.628 \\
\hline $\mathrm{X}_{1}$ - фрінансові ресурси & 0.848 & 1 & $0.721^{*}$ & 0.433 \\
\hline $\mathrm{X}_{2}$ - обсяги виробництва & 0.776 & 0.721 & 1 & 0.797 \\
\hline $\mathrm{X}_{9}$ - експорт & 0.628 & 0.433 & 0.797 & 1 \\
\hline
\end{tabular}

При порівнянні приватних коефіцієнтів кореляції з парними видно, що спостерігається сильний зв'язок 3 результатом (основні засоби) та іншими факторами. Кореляційний аналіз є підтвердженням сценарного аналізу, де в якості основних факторів виступають: фінансові ресурси - $\mathrm{X}_{1}$, обсяги виробництва - $\mathrm{X}_{2}$, експорт - $\mathrm{X}_{9}$.

Рівняння множинної лінійної регресії рівня основних засобів $(Y)$, має вигляд: 
$Y=-8,697,277+0.067 x_{1}+0.102 x_{2}+3,918 x_{9}(2)$

Отримане рівняння регресії дозволяє здійснити достовірний прогноз для $83 \%$ даних $\left(\mathrm{R}^{2}=0.83\right)$. Модель адекватна досліджуваним даним на підставі критерію Фішера.

Розглянемо рівняння регресії для цільових факторів при впливі важелів у Таблиці 4.

Таблиця 4. Лінійні залежності для прогнозу факторів системи «основні засоби»

\begin{tabular}{l|c:c}
\hline \multicolumn{1}{c|}{ Фактор } & Регресія & R2 \\
\hline Х1- фінансові ресурси & $Y=803,166.100+8.762 x_{3}-17.834 x_{7}-761.105 x_{8}+40.051 x_{11}$ & 0.91 \\
\hdashline $\begin{array}{l}\text { Х2- обсяги } \\
\text { виробництва }\end{array}$ & $Y=113,922.947+0.251 x_{3}-0.505 x_{7}-33.546 x_{8}+5.284 x_{11}$ & 0.83 \\
\hdashline Х9- експорт & $Y=11,963.015+0.21 x_{3}-0.073 x_{7}-4.727 x_{8}+1.035 x_{11}$ & 0.79 \\
\hline
\end{tabular}

Таким чином для даної системи «основні засоби» прогноз побудований на апроксимації функціями в 2 етапи. Перший етап прогнозування визначення рівнянь регресії для цільових факторів, де в якості змінних використовуються фактори - важелі, другий етап - прогнозування визначення рівнянь регресії для основних засобів, де в якості змінних використовуються цільові фактори (Рисунок 7).

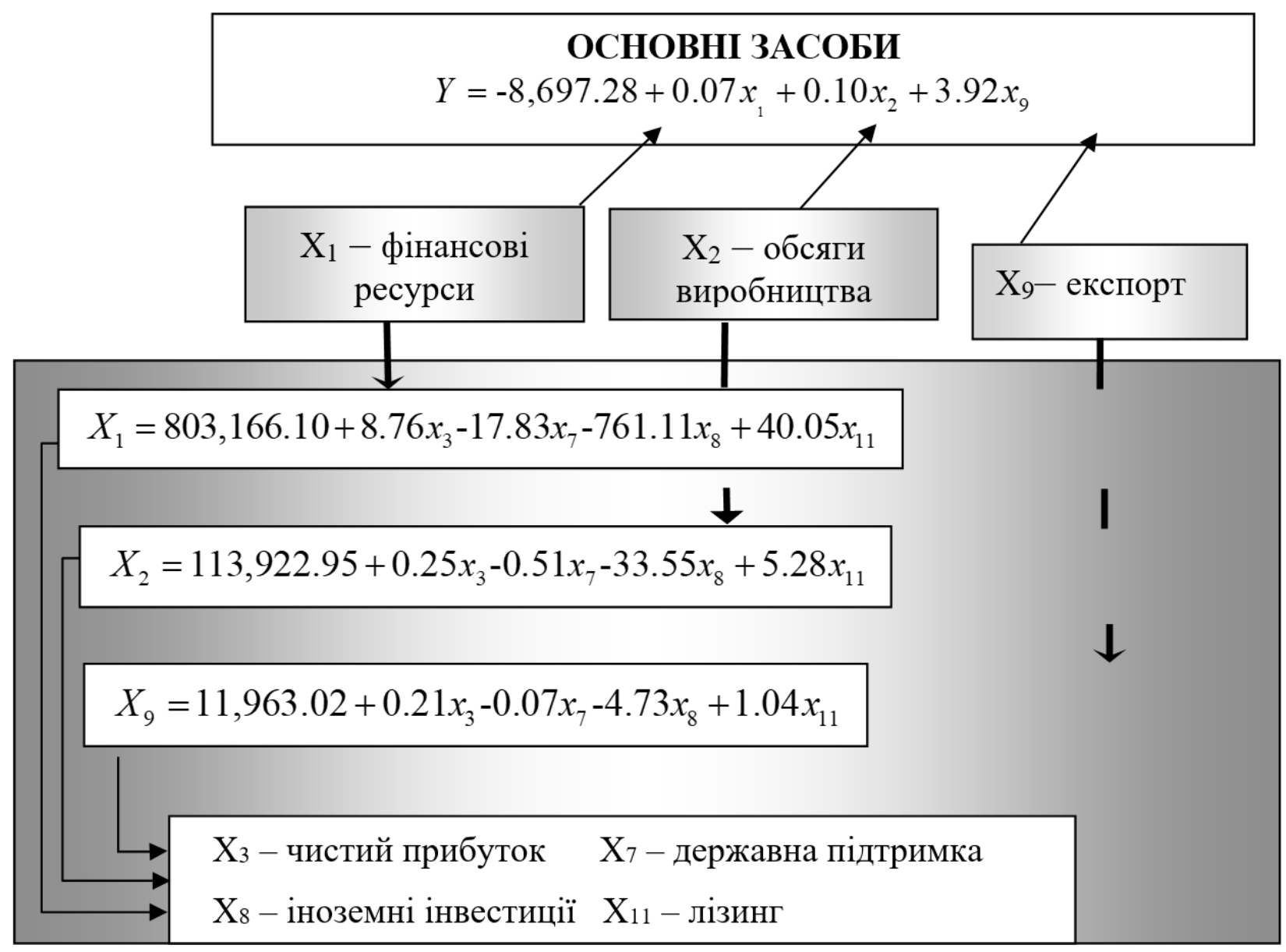

Рисунок 7. Залежності для прогнозу факторів системи «основні засоби» 
При фіксованих значеннях факторів отримані поверхні (Рисунок 8) які дозволяють прогнозувати розмір основних засобів при впливі цільових факторів.

Рівняння нелінійної моделі від цільових факторів має вигляд:

1. $Z=-219,180-1.175 \mathrm{x}_{1}+6.843 \mathrm{x}_{2}-0.000004 \mathrm{x}_{2}^{2}$,

де $\mathrm{X}_{1}$ - фінансові ресурси, $\mathrm{X}_{2}$ - обсяги виробництва.

2. $Z=34,496.36-0.281 \mathrm{x}_{1}+6.0845 \mathrm{x}_{9}-0.00000006 \mathrm{x}_{1}^{2}+0.00003 \mathrm{x}_{1} \mathrm{x}_{9}-0.0004 \mathrm{x}_{9}^{2}$,

де $\mathrm{X}_{1}$ - фінансові ресурси, $\mathrm{X}_{9}$ - експорт - рівняння поверхні.

3. $Z==564,600-1.932 \mathrm{x}_{2}-79.16 \mathrm{x}_{9}+0.00005 \mathrm{x}_{2}^{2}-0.0004 \mathrm{x}_{2} x_{9}+0.0043 \mathrm{x}_{9}^{2}$,

де $\mathrm{X}_{2}$ - обсяги виробництва, $\mathrm{X}_{9}$ - експорт - рівняння поверхні (Рисунок 8).

На підставі даних (Рисунок 8. а)) можна стверджувати, що основні засоби досягають найбільшого значення при максимальному експорті 9,000-13,000 млн доларів США, при обсягах виробництва більше 130,000 млн грн, що складе 6.92-10\% від обсягу виробництва сільськогосподарської продукції.

Також можна стверджувати (Рисунок 9. б)), що найбільше значення основних засобів досягається при сумі фінансових ресурсів більше 800,000 млн грн, при експорті в межах 15,000-19,000 млн доларів США, що складе 9.38-11.88\% від суми фінансових ресурсах.

\section{ВИСНОВКИ}

Таким чином, в статті на основі когнітивного моделювання виявлено фактори, що впливають на процес відтворення основних засобів у сільськогосподарських підприємствах України з урахуванням нестійких умов зовнішнього середовища. При цьому здійснено імітаційне моделювання поведінки досліджуваної
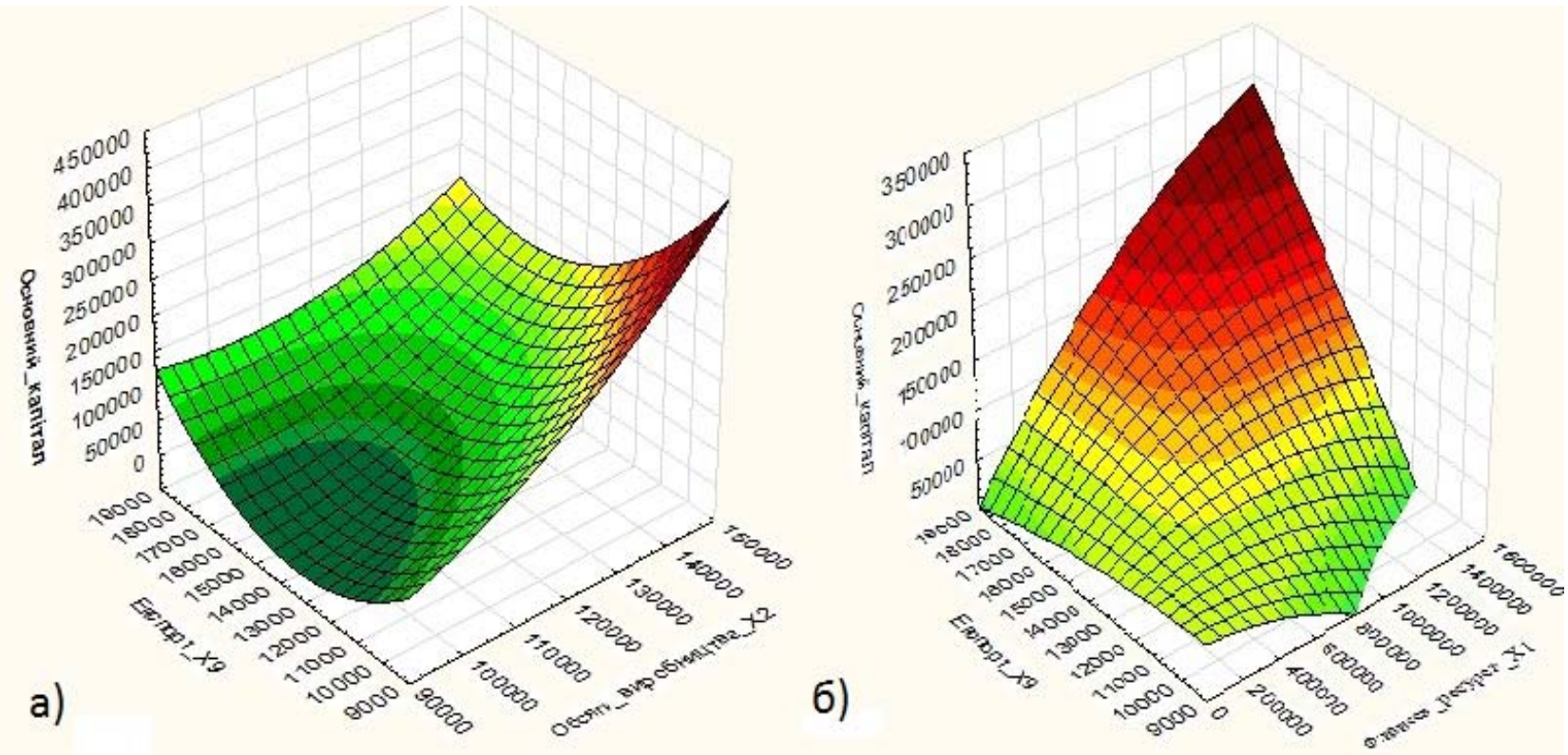

Рисунок 8. Поверхні моделей основних засобів для факторів: а) X2, Х9 (X2 - обсяги виробництва, Х9 - експорт); б) X1, Х9 (X1 - фінансові ресурси, Х9 - експорт) 
системи «основні засоби» на підставі сценарного дослідження. Розглянуті сценарії дозволяють зробити висновок, що основними факторами, які впливають на зміни в в системі основні засоби є: розмір прибутку, що отримують підприємства аграрної галузі, державна підтримка сільськогосподарських товаровиробників, іноземні інвестиції у сільське господарство та фінансування основних засобів на основі лізингу. Саме на цих факторах повинна бути сконцентрована увага в процесі стратегічного управління фінансуванням відтворення основних засобів сільськогосподарських підприємств.

\section{СПИСОК ЛІТЕРАТУРИ:}

1. Axelrod, R. (1976). The Structure of Decision: Cognitive Maps of Political Elites. Princeton: University Press.

2. Borisov, V. V., Bychkov, I. A., Dementyev, A. V., Solovyev, A. P., \& Fedulov A. S. (2002). Компьютерная поддержка сложньх организационно-технических систем [Kompyuternaya podderzhka slozhnykh organizatsionno-tekhnicheskikh sistem] (154 p.). Moskva: Goryachaya liniya - Telekom.

3. Eden, C. (1988). Cognitive mapping. European Journal of Operational Research, 36, 1-13. https://doi.org/10.1016/0377-2217(88)90002-1

4. Filippova, N. M. (2011). Когнітивне моделювання як окрема дисципліна [Kohnityvne modeliuvannia yak okrema dystsyplina]. Humanitarnyi visnyk NUK, 4, 53-55. Retrieved from http://eir.nuos.edu.ua/xmlui/handle/123456789/1593

5. Kadiievskyi, V. A., \& Perkhun, L. Р. (2016). Когнітивне моделювання прийняття управлінських рішень на підприємстві [Коһnityvnе modeliuvannia pryiniattia upravlinskykh rishen na pidpryiemstvi]. Scientific Bulletin of the National Academy of Statistics, Accounting and Audit, 3, 48-56. Retrieved from http://nbuv.gov.ua/UJRN/nvhastat 201638

6. Kosko, B. (1986). Fuzzy cognitive Maps. International Journal of Man-Machine Studies, 24(1), 65-75. https://doi.org/10.1016/S0020-7373( 86) $80040-2$

7. Kulynych, A. A. (2010). Компьютерные системы моделирования когнитивных карт: подходы и методы [Котруuternyуе sistemy modelirovaniya kognitivnykh kart: podkhody i metody]. Problemy upravleniya, 3, 2-16. Retrieved from http://www.mathnet.ru/php/archive.phtml? wshow=paper\&irnid=pu\&paperid=27\&option lang=rus

8. Maksimov, V. I., Kornoushenko, Ye. K., Kachayev, S. V. (1998). Когнитивные технологии для поддержки принятия управленческих решений [Kohnytyvnye tekhnolohyy dlia podderzhky pryniatyia upravlencheskykh reshenyi]. Tekhnologii informatsionnogo obshchestva 98 - Rossiya. Retrieved from www.iis.ru/events/19981130/maximov.ru.html

9. Nazarova, O. P., \& Herhets, A. Y. (2011). Когнитивный подход к формированию системы рычагов регионального развития [Kognitivnyy podkhod $\mathrm{k}$ formirovaniyu sistemy rychagov regional'nogo razvitiya]. Naukovyi visnyk Lvivskoho natsionalnoho universytetu veterynarnoi medytsyny ta biotekhnolohii im. Gzhytskoho, 1(2), 118-122. Retrieved from http://nbuv.gov.ua/UJRN/nvlnu $2011 \quad 13 \quad 1 \% 282 \% 29 \quad 22$

10. Pashkova, Н. (2016). Когнітивне моделювання регіонального розвитку у державному управлінні [Коһnityvne modeliuvannia rehionalnoho rozvytku u derzhavnomu upravlinni]. Efektyvnist derzhavnoho upravlinnia, 1-2(1), 218-228. Retrieved from: http://www. lvivacademy.com/vidavnitstvo 1/edu 46/fail/ch1/27.pdf

11. Roberts, F. (1978). Graph Theory and its Applications to Problems of Society (122 p.). Philadelphia: Society for Industrial and Applied Mathematics.

12. Savchuk, O. Р. (2014). Використання когнітивного моделювання для дослідження демографічної системи [Vykorystannia kohnityvnoho modeliuvannia dlia doslidzhennia demohrafichnoi systemy]. Naukovyi visnyk Khersonskoho derzhavnoho universytetu. Seriia Ekonomika, 5(4), 240-244. Retrieved from: http://www.ej.kherson.ua/journal/economic 05/273.pdf

13. Shakhovalova, Y. О. (2017). Фінансове забезпечення відтворення основних засобів аграрних підприємств [Finапsоvе zаbеzресhеппіа vidtvorennia osnovnykh zasobiv ahrarnykh pidpryiemstv] (Ph.D. Thesis) (183 p.). Kyiv: Kyivskyi Natsionalnyi Ekonomichnyi Universytet imeni Vadyma Hetmana. Retrieved from https://kneu.edu.ua/userfiles/d-26.006.04/2017/Shahovalova dis.pdf

14. Shemaieva, L. G. (2005). Методика організації проведення колективної багатоваріантної експертизи ринкових ситуацій в ході планування сценаріїв управління взаємодією підприємства із зовнішнім середовищем [Metodyka orhanizatsii provedennia kolektyvnoi bahatovariantnoi ekspertyzy rynkovykh sytuatsii v khodi planuvannia stsenariiv upravlinnia vzaiemodiieiu pidpryiemstva iz zovnishnim seredovyshchem]. Komunalne hospodarstvo mist, 62, 270-278. Retrieved from https://khg.kname.edu.ua/index.php/khg/ article/view/2375/2360

15. Zynovev, Y. F. (2008). Формирование и реализация кадрового экономического потенциала в аграрной сфере [Fоrтуголапуе у геаlyzatsyia kadrovoho эkonomycheskoho potentsyala v ahrarnoi sfere] (407 p.). Simferopol: Feniks. 